\title{
植物性食品中のビタミン $\mathrm{B}_{12}$ について
}

(昭和 38 年 11 月 12 日受理)

\author{
古武 彌 三* 小野 忠 義* \\ Vegetable Foods and Vitamin $\mathrm{B}_{12}$ \\ Yazo KOTAKE and Tadayoshi ONO \\ (The Osaka Public Health Institute : \\ 1, Morimachiminami, Higashinari-ku, Osaka)
}

\begin{abstract}
Although it is considered that vitamin $\mathrm{B}_{12}$ and its analogues are not contained in vegetable foods as are they often called "Animal Protein Factor", it was found that vitamin $B_{12}$ group was contained in such vegetables grown in the mud as arrow head (Sasittaria sagittifolia L. var. sinensis Makino), Lotus-rhizome (Rhizome of Nelumbo nucifera), Brasenia schreberi, and also in bamboo sprout grown in the soil, but these amounts were not so much.
\end{abstract}

(Received November 12, 1963)

\section{I 緒 言}

ビタミン $\mathrm{B}_{12}$ 同族体は Animal protein factor の別 名をもって呼ばれるごとく，動物性タンパク質には含ま れが，植物性タンパク質には含まれないものとされてい る.

$\mathrm{B}_{12}$ の作用について重要なものをあげるならば，まず第 1 は核酸合成作用1) 3) である. とくに $\mathrm{B}_{12}$ は thymidine らの riboside の合成に関与し， $B_{12}$ が久乏する と，血球は正常な成熟 maturationを遂げることができ ない.つぎに抗脂肪肝作用 ${ }^{4)}$ ，メチル基転移作用 ${ }^{5)}$ ， ア ミ／酸中間代謝賦活作用 ${ }^{617)}, \mathrm{SH}$ 基活性化作用 ${ }^{819)}$, 内分 泌機能調節作用10)〜13)等である.

Barker らは微生物あるいは動物の肝蔵より adenyl cobamide coenzyme ${ }^{14) 15}$, benzimidazolyl cobamide coenzyme, および dimethylbenzimidazolyl cobamide coenzyme 等の cobamide coenzyme ${ }^{16) 17)}$ を分離し, その作用を明らかにした. cobamide coenzymeの構造 はなお充分明らかではないが，Cyano 基を含まず, adenine 分子が cyano 基によって占められていた co-cordination site で結合しているものと考えられる. したがって $\mathrm{B}_{12}$ の奏在形態は多種多様であり，その作用 も生理的に重要なものが多く，不可欠なものであると考 えられる.

ところが日本においても欧米においても菜食主義

* 大阪府立公臬衛生研究所 :

大阪市東成区森町南 1 丁目
Vegetarianism なるものが存在し、ことに宗教的背景 をもって行なわれる菜食主義のなかには㧛重なものもあ る.

この純菜食者を Vegan と晿えているが，長年月にわ たる厳重な菜食にもかかわらずなんらの症状を訴えない ものもかなりに存在している.

このような理由から $\mathrm{B}_{12}$ の腸管内合成を唱える人もあ るであろうが，腸の下部において微生物によって $\mathrm{B}_{12}$ が たとえ合成されたとしても吸収利用されることには多少 の難点があり，ことに $\mathrm{B}_{12}$ の吸収利用には内因子18) 21) を必要とする事実を考え合わせるとその困難さを想像す ることができる.

われわれはビタミン $\mathrm{B}_{12}$ 同族体は植物にもわずかなが ら存在するものと考え， クワイ、レンコン, ジュンサ イ,タケノコについて笑験を進め, とくにタケノコには かなりの $\mathrm{B}_{12}$ 活性を有することを知ったので, ここに報 告する次第である.

III実験方法ならびに実験成綡

（1）植物性食品とくにクワイ，レンコン：ジンサイ 中のビタミン $\mathrm{B}_{12}$ の定量

$\mathrm{B}_{12}$ の定量は米国薬局法 ${ }^{22)}$ 污準じて，L. leichmannii (ATCC 7830) を用いて微生物学的に行なったが， $L$. leichmannii に対しては, thymidine, pseudo- $\mathrm{B}_{12}$, そ の他の物質が活性を有するので, 活性の高いクワイにつ いてはアルカリもしくは $\mathrm{H}_{2} \mathrm{O}_{2}$ 処理によって $\mathrm{B}_{12}$ を不活 性とし，なお残存する $\mathrm{B}_{12}$ 以外の物質に基うく活性を補 
正し， $\mathrm{B}_{12}$ 同族体に基づく活性のみを $\mathrm{B}_{12}$ として表わす ことにした.

\section{a) 検液の調製}

レンコンは皮をむき，ジュンサイは市販ビン詰のもの をそのままでいずれも精密に科量し，ホモジナイズし て, これに M/15 リン酸塩緩衝液 $(\mathrm{pH} \mathrm{6.5)を} 10 \mathrm{ml}$ 加 え， $100^{\circ}$ で20分間抽出する. さらに蒝留水を加えて全量 を $100 \mathrm{ml}$ とする. つきに遠沈して上清を蒸留水で 2 倍 に希勫して検液とした。

クワイは皮をとり約 $15 \mathrm{~g}$ 精密に科量し， M/15 リン酸 塩緩衝液 $(\mathrm{pH} \mathrm{6.5)} \mathrm{を} 10 \mathrm{ml}$ 加え, 蒸留水で $100 \mathrm{ml}$ と し, $100^{\circ}$ で20分間抽出する.つぎに trypsin (Merck), Takadiastase (三共) を各 $20 \mathrm{mg}$ 加え消化後, 酵素を 不活性化し、この抽出試料のろ液 $5 \mathrm{ml}$ ずつを 2 個の 100 $\mathrm{ml}$ フラスコによる.

一一方は全量を $100 \mathrm{ml}$ にして $\mathrm{B}_{12}$ 活性を測定する. 他 のフラスコには $\mathrm{B}_{12}$ 同族体以外の残存活性を知るため に、このろ液をアルカリ処理，あるいは $\mathrm{H}_{2} \mathrm{O}_{2}$ 処理した のち活性を測定補正した，同時に対照として試料に加え

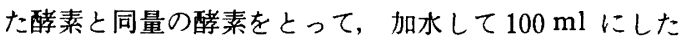
ものを作って $\mathrm{B}_{12}$ 活性を測定補正した.

アルカリ処理 ${ }^{23)} の$ 条件 : 前記の試料 $5 \mathrm{ml} に 0.2 \mathrm{~N} に$ なるように $\mathrm{NaOH}$ を加え, $100^{\circ}$ で 30 分加熱する.つ いで $\mathrm{HCl}$ で $\mathrm{pH} 6.5$ に修正し蒸留水を加え $100 \mathrm{ml}$ と し、その $1 \mathrm{ml}$ をとって全量 $5 \mathrm{ml}$ の測定系で定量した。

なお実験条件を確かめるため $\mathrm{B}_{12}$ を $0.1 \mathrm{~m} \mu \mathrm{g} / \mathrm{ml} に な$ るように加えて同様のアルカリ処理を行ない， $\mathrm{B}_{12}$ の分 解を検查した。

$\mathrm{H}_{2} \mathrm{O}_{2}$ 処理 ${ }^{24)}$ の条件: 試料 $5 \mathrm{ml} に \mathrm{HCl} 1 \mathrm{ml}$ と $30 \%$ $\mathrm{H}_{2} \mathrm{O}_{2} 3$ 滴を加え， 1 時間放置後 $\mathrm{NaOH}$ で $\mathrm{pH}$ 6.5に修 正し，蒸留水を加えて全量を $100 \mathrm{ml}$ とした. $\mathrm{H}_{2} \mathrm{O}_{2}$ 非処 理の場合は試料 $5 \mathrm{ml}$ をとり, 加水して $100 \mathrm{ml}$ とした。

b) cyanocobalamin 標準液

ビタミン学会の cyanocobalamin を $1000 \mathrm{~m} \mu \mathrm{g} / \mathrm{ml} に$ なるように25\%アルコール溶液で希釈し, 暗冷所に保存 して用時さらに適宜に希釈した。

c) 基碟培地

ライヒマニ用のビタミン $\mathrm{B}_{12}$ 定量用基礎培地「ニッサ ソ」またはDifco を指定濃度に作成し， $\mathrm{pH} 6.5$ に修正 し, $120^{\circ}$ で20分隇菌して用いた。

\section{d）接種菌液}

接種用培地に20～24時間培荃したものを減菌生理食塩 水で菌体を 3 回洗浄し, 遠心沈澱する. この操作で菌体 表面の $\mathrm{B}_{12}$ を洗い落とし, 最後に減菌生理食塩水で原量 の約50倍になるように菌体浮遊液をつくり, 接種菌液と する.

e）接種ならびに培養

武㐟菌は微量の $\mathrm{B}_{12}$ や洗浄剂の痕跡にきわめて敏感で あるから，完全に除去し $200^{\circ} て ゙ 2$ 時間乾熱隇菌したもの
を用いた、検量線は第 1 図のように作成し，検体につい ては調製試料 $1 \mathrm{ml}+$ 蒸留水 $1.5 \mathrm{ml}+2$ 倍濃厚培地 2.5 $\mathrm{ml}$ とし， $120^{\circ}$ で 5 分間隇菌する. $\mathrm{B}_{12}$ 溶液を添加しな いものには菌接種をせずに、これをブランクとし，他の 試験管には前記調製接種菌液を 1 滴ずつ加え 35 〜 $37^{\circ}$ で 20〜24時間培養した。

f）菌体增殖度の測定

コタキ光電比色計で $660 \mathrm{~m} \mu$, cell $1 \mathrm{~cm}$ の条件で透 過率を求めた。

g) L. leichmannii に対する $\mathrm{B}_{12}$ 活性の定量例

試料の L. leichmannii に対する活性を比濁法によっ て定量した 1 例を示すとつぎのとおりである，検量線は 第 1 网のようになる.

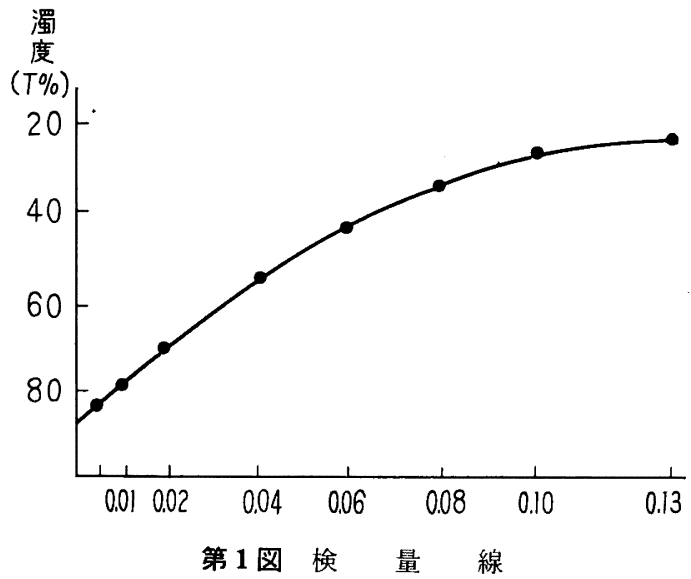

第 1 表 クワイの L. leichmannii 活性

\begin{tabular}{|c|c|c|c|c|}
\hline 番号 & 試 & \multicolumn{3}{|c|}{ 透過率 (T\%) } \\
\hline 1 & 酵 素 だけ（対照） & 94.0 & 92.5 & 92.5 \\
\hline 2 & $100^{\circ}, 30$ 分 抽 出 & 90.0 & 89.5 & 88.5 \\
\hline 3 & 酵 素 消 化 抽 出 & 66.0 & 66.0 & 66.0 \\
\hline 4 & 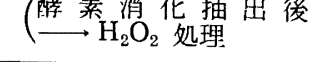 & 70.0 & 70.0 & 70.0 \\
\hline 5 & $\begin{array}{l}\text { (酝素消 化抽出後 } \\
\longrightarrow \\
\longrightarrow\end{array}$ 処理 & 64.5 & 64.5 & \\
\hline 6 & $\begin{array}{c}\left(\begin{array}{c}\text { 酵素消化 抽出 } \\
+\mathrm{B}_{12} 0.05 \mathrm{~m} \mu \mathrm{g}\end{array}\right) \longrightarrow \\
\text { アルカリ処理 }\end{array}$ & 63.5 & 65.0 & 64.5 \\
\hline 7 & 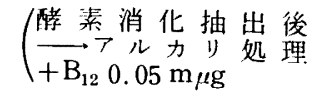 & 43.5 & 43.0 & 42.0 \\
\hline
\end{tabular}

みかけの $\mathrm{B}_{12}$ 総量

$386 \mathrm{~m} \mu \mathrm{g} \%$

$\mathrm{H}_{2} \mathrm{O}_{2}$ 処理後の残存活性

$293 \mathrm{~m} \mu \mathrm{g} \%$

$\mathrm{B}_{12}$ 同族体

$93 \mathrm{~m} \mu \mathrm{g} \%$

われわれが行なうアルカリ加熱処理の条件で $\mathrm{B}_{12}$ が完 
全に破壊されるかどうかを調べるための奏験として第 1 表の 6，5を比較してみた．すなわちクワイの酵素消化 抽出したものに $\mathrm{B}_{12}$ を加えてアルカリ処理したものと， クワイの酵素消化抽出したそのものをアルカリ処理して $\mathrm{B}_{12}$ を破壊した場合とを比較すると全く透過率が同じで あることから添加した $\mathrm{B}_{12}$ は完全に分解されることが確 認された. したがって非処理の活性からアルカリ処理の 值をひいたものが補正值すなわち $\mathrm{B}_{12}$ 同族体の活性値で ある.

しかし実際にはアルカリ処理を行なった場合には多少 着色し，誤差の原因となるので濁度よりも酸度滴定によ るか $\mathrm{H}_{2} \mathrm{O}_{2}$ 処理を行なった方が便利であり， $\mathrm{H}_{2} \mathrm{O}_{2}$ 処理 によっても $\mathrm{B}_{12}$ 同族体の活性は容易に消失するのでもっ ぱら $\mathrm{H}_{2} \mathrm{O}_{2}$ 処理を行なった。

第 2 表 L. leichmannii に対する $\mathrm{B}_{12}$ 活性の 定量値（数字は $\mathrm{B}_{12}$ としての $\mathrm{m} \mu \mathrm{g} \%$ )

\begin{tabular}{|c|c|c|c|c|c|c|}
\hline 試 & 料 & $\begin{array}{l}\text { みかけ } \\
\text { の } \mathrm{B}_{12}\end{array}$ & \multicolumn{2}{|c|}{ みかけアルカリ $\mathrm{H}_{2} \mathrm{O}_{2}$ 処 } & 補正値 & 備考 \\
\hline レン & 1 & * 150 & & & & 比濁 \\
\hline コン & 2 & * 60 & & & & 比濁 \\
\hline \multicolumn{2}{|c|}{ ジェンサイ } & * $\quad 18$ & & & & 比濁 \\
\hline \multirow{3}{*}{ ク } & 1 & * 150 & & & & 比濁 \\
\hline & 2 & 450 & 320 & & 120 & 酸度= \\
\hline & 3 & 402 & & 268 & 134 & 比濁 \\
\hline \multirow[t]{2}{*}{$\nabla$} & 4 & 775 & & 520 & 255 & " \\
\hline & 5 & 810 & & 420 & 390 & " \\
\hline \multirow[t]{2}{*}{ イ } & 6 & 386 & & 293 & 93 & " \\
\hline & 7 & 1,350 & & 1,070 & 280 & " \\
\hline
\end{tabular}

*酵秦消化を行なわない場合

2) $\mathrm{B}_{12}$ 活性物質のペーハークロシトフラフィーによ る娭討

L. leichmannii については $\mathrm{B}_{12}$ の他に2，3の生育因 子 ${ }^{25)}$ が知られているので，われわれも $\mathrm{B}_{12}$ 活性の位置を 明らかにするためにペーパークロマトグラフィーを行な った（使用口紙は東洋口紙 No. 50）。

使用標準液の濃度 :

(1) ビタミン $\mathrm{B}_{12}$ 標準液 $1000 \mu \mathrm{g} / \mathrm{ml}$

(2) チミジン溶液 : Nutritional Biochemicals Co.の チミジンを $3 \mathrm{mg} / \mathrm{ml}$ の濃度に $50 \%$ ェノールに溶 解したもの

原点にスポットした標準夜量と検体量

微生物定量法に用いたクワイ試料の酵素消化抽出夜を 減王下で約10倍に濃縮し，毛細ピペットで $0.006 \mathrm{ml}$ を 原点に帯状につけ，対照のチミジン溶液は $0.004 \mathrm{ml}$ を $\mathrm{B}_{12}$ 標準液は $0.002 \mathrm{ml}$ を原点につけ，できるだけ広が らないように注意した。

\section{展開条件}

（1）展開剂は $n$-ブタノール $100 \mathrm{ml}$, 水酢酸 $20 \mathrm{ml}$, 蒸 留水 $40 \mathrm{ml}$ で19持間室温で展開した。

(ロ) 展開剂は水飽和 $n$-ブタノールで室温で 17 時間展 開した。

\section{活性位置の検出}

原点から $1 \mathrm{~cm}$ ずつロ紙片を切りとり, 直径 $1 \mathrm{~cm} \mathrm{の}$ 無菌試験管に入れ，L. leichm:nnii を用いて $1 \mathrm{ml}$ 系の 測定法（培地：Difco $\mathrm{B}_{12}$ 定量用培地）で24特間 $37^{\circ}$ で培 養し、コタキ光電比色計 $660 \mathrm{~m} \mu, 0.5 \mathrm{~cm}$ の cell で濁 度を測定し, 增殖位置を求めた。

(1) 第 2 図のようにクワイ抽出夜の増殖位置は 3 加所 にあり，一番濃く現われる位置は $\mathrm{B}_{12}$ のスボットよりや や原点に近い、またその後の実験においてクワイあるい はタケノコの抽出液に $\mathrm{B}_{12}$ を添加した場合には $\mathrm{B}_{12}$ 単独 の場合より Rf が少し異なってくることを経験したの で,この成績のみをもって，クワイ中の $\mathrm{B}_{12}$ 活性物質は cyanocobalamin とは相違する物質であるともいいえ ない.チミジンの活性位置はRf 0.6 であってクワイ抽 出液からほほこれに合致するRf 0.58 位置に活性か認 められる.

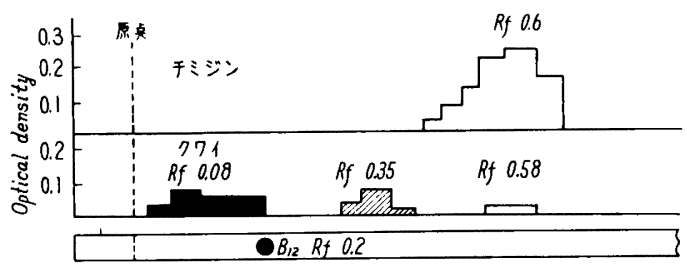

第 2 図クワイ抽出液のペーパークロマトグラフィー-

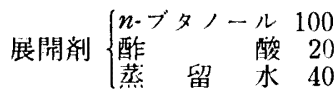

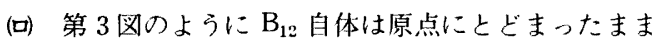
全然動かなかった.クワイの活性は Rf 0.23 と 0.500 位 置にも現われたが，原点に最も濃いスポットが残った。

チミジンのスポットはRf 0.49であったが，これは多 くの研究者によって報告された結果にほぼ一致し， Rf 0.5 の活性に相当するものと考えられる.

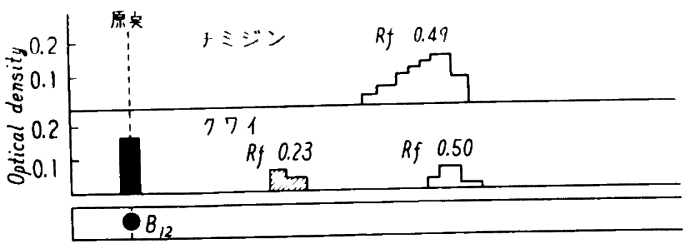

第 3 図クワイ抽出夜のペーパークロマトグラフィー 展開剤水飽和 $n$-ブタノール 
3）クワイ抽出液アルカリ処理後のペーパークロマト グラフィー

クワイ試料を酵素消化抽出したろ液 $5 \mathrm{ml}$ に $2 \mathrm{~N}-\mathrm{Na}$ $\mathrm{OH} 0.55 \mathrm{ml}$ を加えて $100^{\circ}$ で30分加熱し, $\mathrm{HCl}$ で $\mathrm{pH}$ 6.5 に中和する. 次いで乾涸するまで水浴上で乾燥し, 無水エチルフルコール $5 \mathrm{ml}$ を加えてろ過し，ろ夜を濃 縮乾涸し， $0.25 \mathrm{ml}$ の水を加えて溶かす。この液0.006 $\mathrm{ml}$ をロ紙に帯状につけ，対照にはアルカリ処理しない で同様に操作した液をつける．また端の口紙には $\mathrm{B}_{12}$ を スポットして目印とした.

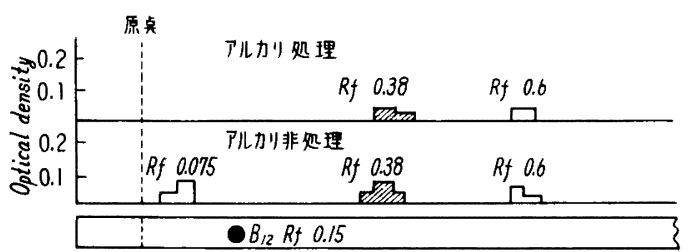

第 4 図クワイ抽出液アルカリ処理後のペーバー クロマトグラフィー

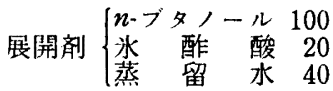

その結果第 4 図のようにアルカリ非処理の場合には Rf $0.075 に$ 活性が現われるが，アルカリ処理の場合には 現われなかったので，アルカリ処理によって，この位置 にあった活性物質は破堙されたことを示す．他の活性位 置については非処理の場合と同様に処理した場合でも同 じ位固に活性が現われた。 したがって Rf 0.075 の活性 物質が $\mathrm{B}_{12}$ 同族体ではないかと考えられる.

4) タケノュの $\mathrm{B}_{12}$ 活性

われわれは多数の植物性食品について $\mathrm{B}_{12}$ を測定した が，そのうちタケノコは最も活性の強いものの1つであ った・ 八チクおよびモウソウの 2 種のタケノコを入手 し皮を取り去り，上部，中部，下部の 3 部位に分け， ホモジナイズし抽出したが，タケノコの場合はクワイの 場合と異なり, 醉素消化を行なっても酵妻消化を行なわ なくても $\mathrm{B}_{12}$ 活性は変化しなかったので, 酵素消化を省 略した，成績は第 3 表に示すとおりであった。

第 3 表 タケノコの種類，部位別の $\mathrm{B}_{12}$ 活性 $(\mathrm{m} \mu \mathrm{g} \%)$

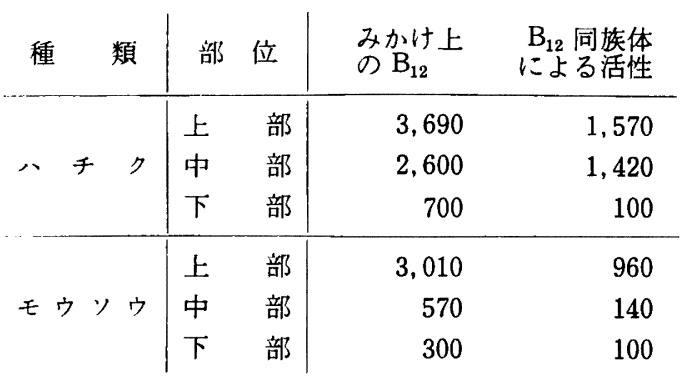

ハチクモウソウともに発育盛んな上部は中部，下部 に比べて L. leichmannii に対する $\mathrm{B}_{12}$ 活性は強く, $\mathrm{B}_{12}$ 同族体による活性として補正された值を揭げたが，この 值から見ても上部は下部の10〜15倍の活性がある.

タケノコの産地によっては人䔬肥料を施すところがあ るといわれるが，実験に使用したタケノコは肥料として もっぱら硫安と尿素が使われていた。

つぎに京都府乙訓郡長岡天神の農業会よりやや多量の タケノコを買い入れ $\mathrm{B}_{12}$ 活性物質の濃縮分離を試み，つ ぎのような処理を行なった.

タケノコ $1.5 \mathrm{~kg}$ をホモジナイズ, 加水全量

$10 \mathrm{~L}$ とする

$100^{\circ} ， 40$ 分間熱抽出

吸引万過, 残渣を除去

活性炭50 g を加えて 1 時間かきまぜ

吸引ろ過

ろ液に再度活性炭を加えて同様に操作

炭末を集め, $\mathrm{NH}_{4} \mathrm{OH}$ で $\mathrm{pH} 8.0$ に修正

$50 \%$ ๖トン $400 \mathrm{ml}$ を加え，1時間かきまぜ

吸引ろ過

ろ液は減圧濃縮, アセトン, 水分除去

（活性収率 約 $80 \%$ )

ここに得た $\mathrm{B}_{12}$ 活性物質の濃縮液について L. leichmannii に対する値を測定したところ，
みかけ上の $\mathrm{B}_{12}$ 值
$5,824 \mathrm{~m} \mu \mathrm{g} \%$
$\mathrm{B}_{12}$ 同族体による活性值
$2,016 \mathrm{~m} \mu \mathrm{g} \%$

の成績を得た。われわれは日本ビタミン学会から Och romonxs malhcmensis の譲渡を受けて実験していたが 当時の Ochromonxs malhamensis の感受性はよくなか ったので放固していたため死隇させ困却していたとこ ろ，東京米大の上田教授のお世話によって Dr. Hutner の所有する原虫の分譲を得たので，上記タヶノコの濃縮 液について実験し

Ochromonas malhamensis 值 $\quad 50 \mathrm{~m} \mu \mathrm{g} \%$ になる値を得た. 目下のところでは L. leichmannii 值 と O. malhamensis の值の間の大きな差異を説明するこ とは困難で, 他日の研究によって解決したいと考えてい る.

\section{III 考 察}

Gray および Daniel ${ }^{26)}$ は米国 Georgia 州の Blairsville 地方産カブラ葉に $\mathrm{B}_{12}$ の含有されることを報告し Ochromonas の増殖によると $7 \mathrm{~m} \mu \mathrm{g} / \mathrm{g}$ であるという。

われわれは泥のなかに生育するクワイ、レンュン, ュンサイ等にビタミン $\mathrm{B}_{12}$ 活性の含まれることを明らか にした.

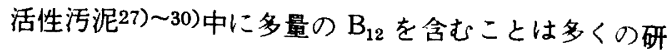


究者によって明らかにされたが，クワイ，レンコン等の 生育する普通の泥にどのぐらいの $\mathrm{B}_{12}$ が含まれるかは明 らかでない.しかし普通の泥に多少存在したとしても不 思議はないであろう。

高田, 酒井沢 ${ }^{31}$ が大根を用いて砂栽培を行ない $\mathrm{B}_{12}$ の 吸収を調べたところ， $\mathrm{B}_{12}$ を投入したものとしないものと では $\mathrm{B}_{12}$ 含量の差が著しく，根部の $\mathrm{B}_{12}$ はあたかも唚透作 用によって植物体に入ったかの感があると述べている.

したがって泥のなかで細菌, Protozoa, Zoogloea 等 によって合成された $\mathrm{B}_{12}$ がこれらの植物に浸透または吸 収されたのではないかという考え方もできる.

ところがタケノコの場合は土锿の $\mathrm{B}_{12}$ あるいは $\mathrm{B}_{1:}$ 含 有肥料から $\mathrm{B}_{12}$ が移行したとは考えがたい.したがって 植物でも種類によっては $\mathrm{B}_{12}$ を合成しうるのではないか と考えられる.

もしも植物に $\mathrm{B}_{12}$ が完全に含まれていないものなら ば，簃重な菜食者は巨赤芽球性の貧血を起こし，健康を 維持しえないであろうが，菜食者に障害が起こったとし てもその障害が知覚異常 (Paresthesia)，あるいは春椎 分離症 (Spondylolysis) に近似したPoker back ${ }^{82}$ あ るいは Vegan back と呼ばれる脊の痛みを訴える程度 にとどまるのは，植物にも $\mathrm{B}_{12}$ を含有している証拠であ ろうと考えられる.

\section{IV 結 論}

$\mathrm{B}_{12}$ 同族体は Animal protein factor と呼ばれ，植物 性食品には含有されないように考えられているが，量的 には少ないが，泥中に育つクワイ，レンュン，ジュンサ イ，土境に育つものではタケノコのなかに含まれること を明らかにしえた。

最後に東京函大の上田喜一教授に䔆しで感謝の意を表 する.

文献

1) W. Shive et al.: J. Biol. Chem. 176, 991 (1948).

2) I. A. Rose et al.: Proc. Soc. Exp. Biol. Med. 79, 541 (1952).

3) C. C. Ungley: Brit. Med. J. ii, 1370 (1940).

4) P. György: Liver Disease, Ciba Foundation 81 (1951).

5) J. A. Stekol et al.: J. Biol. Chem. 186, 343 (1950).

6）市原：第 6 回ビタミン学会特別講演昭和 29 年.
7）内田，槙田：ビタミン 6, 645（昭和28年).

8) J. W. Dubnoff : Arch. Bioch. 27, 466 (1950).

9) C. T. Ling, B. F. Chow : J. Biol. Chem. 202. 445 (1953).

10) J. Meites: Proc. Soc. Exp. Biol. Med. 75, 195 (1950).

11) F. Gassner et al.: ibid. 75, 630 (1950).

12）井上, 他：ビタミン 3, 103， 236, 238, 310 (1950)；4, 147, 203, 212 (1951).

13）松岡：日血会誌. 14，4号 (1951).

14) H. A. Barker et al.: Proc. Acad. Sci. 44, 1093 (1958) ; 45, 521 (1959).

15) H. A. Barker et al.: J. Biol. Chem. 235, 181 (1960).

16) H. A. Barker et al.: ibid. 235, 480 (1960).

17) H. Weissbach, J. I. Toohey, H. A. Barker: Proc. Nat. Acad. Sci. 45, 521 (1959).

18) L. Berk et al.: New Engl. J. Med. 239, 911 (1948).

19) B. E. Hall : Proc. Staff Meeting Mayo Clinic 24, 99 (1949).

20) T. D. Spies et al.: South Med. J. 42, 528 (1949).

21) F. H. Bethell et al.: Univ. Hosp. Bull. Ann. Arbor. Milch 15, 49 (1949).

22) United States Pharmacopoeia XV, 885(1955).

23) C. E. Hoffmann et al.: J. Biol. Chem. 181, 365 (1949).

24）上久保：ビタミン 8, 64 (1955).

25) W. A. Winsten et al.: J. Biol. Chem. 181, 109 (1949).

26) L. F. Gray, L. J. Daniel : J. Nutrition 67, 623 (1959).

27) S. R. Hoover et al.: Science 114, 213 (1951).

28) S. R. Hoover et al.: Sewage \& Industrial Waste 24, 38 (1952).

29）上久保, 高田：ビタミン 6, 581 (1953).

30）高祜: $\mathrm{B}_{12}$ と APF, 124 南江堂.

31）高田, 酒井沢 : ビタ ミン 9, 443 (1955).

32) F. Wokes, J. Badenoch, H. M. Sinclair: Am. J. Clin. Nutrition 3, 375 (1955); Voeding 16 590 (1955). 